\title{
THE EFFECT OF PRICE ON THE WATERPARK VISITORS' SATISFACTION
}

\author{
Mariaty Ibrahim ${ }^{1} \&$ Musadad $^{2 *}$ \\ ${ }^{1,2}$ Faculty of Social and Political Sciences, Universitas Riau. \\ sadad.sanusi@gmail.com
}

\begin{abstract}
The quality of a good or service is mostly determined by the consumers. Accordingly, satisfying consumers can be attained by providing not only good quality products and services but also other factors, including price. Price issues faced by Queen Star Waterpark in Siak Regency of Riau Province in the past three years have decreased the number of visitors and raised visitors' complaints. This study, therefore, was aimed at finding out the effect of price on visitor satisfaction. The data was collected through conducting an interview with the waterpark manager and distributing questionnaires to 100 respondents as the samples chosen randomly through accidental sampling. To analyze the collected data, simple regression was used, while the hypothesis testing was performed through $t$-test and analysis of the coefficient of determination $(R)$. The analysis results showed that the variable $x$ (price) was proven to significantly affect the variable $y$ (visitor satisfaction). This implies that the waterpark management should consider this and adopt a new approach to pricing.
\end{abstract}

Keywords: waterpark, price, visitor satisfaction

\section{INTRODUCTION}

The development of the tourism industry needs to be supported by the solid support of employers, workers, and government. They have to always cooperate in the spirit of equal partnership and fair to realize industrial peace and industrial progress. The supports from employers, workers, and government are increasingly needed in the future. It is because the public has become more aware that the interests of each party do not need to be contrary to the interests of others. The process of development in Indonesia is still facing problems of expansion of employment opportunities, which is due to the high rate of growth of the labor force. Therefore, the effort and wisdom of the development of small industries which are generally located in rural areas are highly expected. The element of equitable distribution of revenue is an issue which is very essential in national development. Therefore, the attention particularly efforts is needed to increase the income of lowincome groups, thus the disparity between the rich and poor can be reduced.

In addition to the role of government in developing tourism, there is also the role of private sector participation in the tourism industry. In this case of Siak Regency, there is a privately-owned water park called Queen Star Waterpark. Although Queen Star Waterpark is a like game attraction, the owner claimed at the 
inauguration that it was aimed to support the vision of Siak as a center of Malay culture in Riau. The vision is supported by agribusiness, agro-industry, and tourism developed within the religious and prosperous by community 2025 . The existence of Queen Star Waterpark can vary the tourist destinations in Siak in addition to other attractions such as the Palace of Siak, Balai Kerapatan, Tengku Supreme Sultanah Latifah Bridge and others. Queen Star Waterpark is the only attraction of water games in Siak where it has no similar competitor. Hence, it becomes an opportunity and convenience for Queen Star Waterpark in attracting target markets so that it will be visited by many visitors. Queen Star Waterpark offers a variety of rides and attractions to attract potential visitors. The attractions offered by Queen Star Waterpark are presented as follows:

Table 1

Visitor Attractions at Queen Star Waterpark

\begin{tabular}{|c|l|}
\hline No & Rides and Attractions \\
\hline 1. & Stream Pond \\
\hline 2. & Kiddy pool \\
\hline 3. & Slider spiral \\
\hline 4. & Baby pool \\
\hline 5. & Playing fox \\
\hline 6. & Slider \\
\hline 7. & "Spoiled bucket" \\
\hline
\end{tabular}

Source: Queen Star Waterpark, 2018

Table 1 indicates that the tourist attractions at Queen Star Waterpark are highly expected to provide satisfaction for visitors. Basically, the goal of a business is to create satisfied visitors. The visitor satisfaction can create some benefits, i.e. a harmonious relationship between a destination and its visitors and a good foundation for the purchase, which are beneficial for the destination itself. Someone's satisfaction to use the services is a complex process and is affected by various factors like price, so the company must have advantages in establishing a competitive price. Price is one of the important attributes evaluated by visitors so that the company's managers need to understand the role in influencing visitor attitudes. Usually, visitors in using services will compare prices, choose the essentially cheap services, and choose the services that are comparable to the quality or variety of other reasons.

The only marketing mix which generates income or revenue is price, while the other signifies cost. Kotler, et al (2016) define price as simply the amount of money charged for goods or services. To determine price, a company should pay attention to various factors including internal and external factors.

The price must be set appropriately to produce optimal revenue. Various strategies for pricing have been performed by companies. One that is commonly made to attract more visitors to visit is discount or price reduction. However, price discount may be misleading. Falk \& Scaglione (2018) show that that the influence of price 
reduction is insignificant. Even the effect can be negative. Thus, companies must be careful with discount. To address this issue, Malasevska \& Haugom (2017) suggest that alpine ski operators should implement a more dynamic approach to determining the price to increase their revenues.

In the case of the waterpark, Liestiande (2016) claims that both domestic and foreign visitors perceive the price as the main consideration for choosing a waterpark. Her study suggests that domestic visitors want the ticket price of more than IDR 200.000 while the foreign ones prefer the ticket price of more than $\$ 15$. This implies that lower prices are always preferred by visitors. Thus, the strategy for pricing should be also formulated according to visitor preference.

Satisfaction is defined as the level of one's feelings after comparing the performance of a good or service with the expectation (Kotler et al, 2016). In other words, satisfaction means a person's feelings of pleasure or disappointment that arise after comparing the performance of a product and the expectation. Satisfaction with a tourist object means the perception generated before and after visiting the site.

Visitors' satisfaction in the context of water park is determined by various factors, including experience quality and water park image (Jin, Lee, \& Lee, 2015), image and price fairness (Jin, Line, \& Merkebu, 2016), food quality (Lee, 2016), service quality, image, and perceived value (Isnaeni, 2018), and price (Liestiande, 2016). In term of price, Wu, Zhang, \& Qiu (2016) suggest that charges influence visitors entering the ancient villages and towns in China, thus reinforcing local firms' dependence on tickets.

The management of the waterpark industry should be sensitive to the service image and price. This is because these two are perceived as a major consideration for visitors planning to visit waterparks (Jin, Line, \& Merkebu, 2016). Visitors' image of waterparks is usually stimulated by their interactions with the staffs. Thus, waterparks have to be aware of the visitors' satisfaction by taking into account such predictors.

The number of visitors has a major effect on the survival of a company that is engaged in the sale of services since for service companies, visitors are a source of income. The more the number of visitors, the greater the revenue that can be achieved by a company. Visitor perception of the price requires the company to be careful in setting the price at which the price can be accepted by the target market. In terms of the promotion, Queen Star Waterpark has made a serious promotion by using some of the promotional mixes such as advertising, personal selling, sales promotion, and public relations. Based on field phenomenon, visitors admit that they complained about high ticket prices that are not comparable to the benefits obtained. Here are the prices of entry ticket at Queen Star waterpark.

Table 2

Ticket Prices at Queen Star Waterpark

\begin{tabular}{|l|l|}
\hline Ticket Price & Day \\
\hline IDR 40,000 & Tuesday to Friday \\
\hline IDR 50,000 & Saturday to Sunday \\
\hline
\end{tabular}


Source: Queen Star Waterpark, 2018

Table 2 shows that the ticket prices are set without any change in price, although on the school holidays and national holidays. According to information from the manager, with the prices offered, the visitors can enjoy various games and facilities as much as they want. Nevertheless, the manager claims that not all facilities already include the ticket price. There are additional fees for visitors who use several additional facilities as follows:

Table 3

Prices of Facilities at Queen Star Waterpark

\begin{tabular}{|c|l|l|l|}
\hline No. & Facilities & \multicolumn{1}{|c|}{ Price } & \multicolumn{1}{|c|}{ Information } \\
\hline 1. & Parking & $\begin{array}{l}\text { IDR } 2000 / \text { two-wheels } \\
\text { IDR } 5000 / \text { four wheels }\end{array}$ & $\begin{array}{l}\text { Until visitors finish their } \\
\text { visit }\end{array}$ \\
\hline 2. & Float & IDR 15,000 & Limitless time \\
\hline 3. & $\begin{array}{l}\text { Meeting } \\
\text { Room }\end{array}$ & $\begin{array}{l}\text { IDR } 80,000 / \text { pax } \\
\text { IDR } 85,000 / \text { pax }\end{array}$ & A minimum of 50 pax \\
\hline 4. & Gazebo & IDR 150,000/pax & 1 person indefinitely \\
\hline 5. & Locker & IDR 5000/pax & Limitless time \\
\hline 6. & Cafeteria & $\begin{array}{l}\text { According to the } \\
\text { booked menu }\end{array}$ & $\begin{array}{l}\text { Prices of drinks range } \\
\text { from IDR 7000 - } \\
\text { IDR 12,500 foods range } \\
\text { Prices of food } \\
\text { from 10,000 - IDR } \\
23,000\end{array}$ \\
\hline
\end{tabular}

Source: Queen Star Waterpark, 2018

Table 3 specifies the additional facilities provided by Queen Star Waterpark for visitors who require additional facilities. Usually, visitors who want to enjoy the additional facilities directly make a transaction in each of the extra facilities they want, because the waterpark has provided officers at each facility. Table 3 also indicates that the pricing is highly valued by visitors coupled with some of the facilities which require an additional fee. Compared to other tourist destinations existing in Siak Regency, the ticket prices at Queen Star Waterpark are far more expensive. The price of entry ticket at Siak Palace is only IDR 2000 per person for children and IDR 3000 per person for adults. Some visitors asked during the preliminary study admit that they tend to be unhappy with the prices set by the waterpark. Price is part of the marketing mix that should be considered by the company so that the products can be accepted by the market. Therefore, this study was aimed to investigate the effect of the price set by Queen Star Waterpark on the visitors' satisfaction.

\section{METHODOLOGY}

This study employed a quantitative approach. Based on the data collection technique, this study used two types of data, i.e. primary data and secondary data. 
The primary data was elicited through distributing questionnaires to the visitors and conducting interviews with the waterpark manager while the secondary data was collected through documents related to the study. Meanwhile, the population of this study was the visitors of Queen Star Waterpark the subjects for this study amounted to 100 respondents selected randomly using accidental sampling.

The test used to test the partial or individual effect among independent variables was generated from the regression equation. The test individually affected the variable $\mathrm{x}$ (price) and variable $\mathrm{Y}$ (visitor satisfaction). It used the following formula:

$$
\begin{aligned}
& r=\sqrt{n-2} \\
& \quad \sqrt{I-R^{2}} \\
& \text { Where: } \\
& \mathrm{t}_{0}=\text { value of } \mathrm{t} \text { count } \\
& \mathrm{n}=\text { number of samples } \\
& \mathrm{r}=\text { correlation coefficient }
\end{aligned}
$$

In this study, the hypotheses belonged to the alternative or directional hypothesis (Creswell, 2013). The hypotheses statistical formula is presented as follows:

Ha (alternative): $t$ count $>t$ table

Ho (zero): $t$ table $>t_{\text {count }}$

Where:

Ha: price affects visitor satisfaction

Ho: price does not affect visitor satisfaction

\section{RESULTS AND DISCUSSION}

It is very common that visitors are charged for visiting a waterpark or enjoying waterpark facilities and attractions. Once the visitors perceive the price as proper and reasonable, they might have a positive image towards the waterpark they visit. This would bring further consequence, i.e. satisfaction with the waterpark. This was shown by Dulyadhamapiromya \& Supeecha (2018) who suggested that waterpark image and price fairness are two significant factors in predicting visitors' satisfaction.

The effect of the price should not be taken for granted, especially by privately-owned tourist destinations like waterparks. As an amusement park, Queen Star Waterpark has to be sensitive and wise in determining its prices. If not, the visitors could be dissatisfied and, eventually, reluctant to revisit.

\section{Respondents' profiles}

Most of the respondents' age range from 28 - 38 years old (45 respondents) while the lowest ones are aged below 38 years old. Most of the respondents in this study are female with a total of 68 respondents. Most of the respondents are working as civil servants with a total of 38 respondents and followed by those working as entrepreneurs. In the case of educational background, most of the respondents are 
bachelor graduates with a total of 36 respondents. Lastly, in term of visit purpose, all respondents (100) visit the waterpark for recreation.

Based on the results of the interview with the Queen Star Waterpark manager, the waterpark did not have any specific target market. The waterpark wants to reach all circles since it is an amusement park that is suitable for families from all backgrounds, ages, and professions. In addition, the manager admitted that the waterpark had no funding constraints relative to promotional efforts. 1

\section{Data analysis}

Validity and Reliability

This validity test was performed using SPPS version 17 . The $r$ count was higher than $r$ table $(0.201)$ so that it can be concluded that all indicators of pricing and discount, as well as visitor satisfaction, are valid. Meanwhile, in term of reliability, a construct or variable is said to be reliable if it gives the value of Cronbach Alpha of $\geq 0.60$. Based on the calculation, it can be seen that each variable between the price and visitor satisfaction variables generates a Cronbach Alpha value of $\geq 0.60$. Thus, all variables are reliable.

\section{Hypothesis testing}

The hypotheses test was done using a simple regression test. The Simple Linear Regression Analysis was based on the calculation of simple regression of the effect of the price $(\mathrm{X})$ on visitor satisfaction (Y) by using SPSS 17. The calculations show the result follows:

$$
\begin{gathered}
Y=a+b X \\
Y=3.445+0.407 X
\end{gathered}
$$

The meaning of the numbers in the above regression equation is as follows:

- The constant value of (a) is 3.445, meaning that if the price is assumed zero (0), then the perception of visitor satisfaction has a value of 3.445 .

- The regression coefficient value of the variable price is 0.407 , meaning that any increase in the perception of price by 1 unit will increase visitor satisfaction by 0.407 .

Test of the coefficient of determination $(R)$

The results of the Test of the coefficient of determination is shown as follows.

Table 4

Test of the coefficient of determination $\left(\mathrm{R}^{2}\right)$ 
Model Summary ${ }^{\mathrm{b}}$

\begin{tabular}{|l|l|l|l|l|}
\hline Model & R & R Square & Adjusted R Square & Std. Error of the Estimate \\
\hline 1 & $.907^{\mathrm{a}}$ & .823 & .819 & 3.03176 \\
\hline
\end{tabular}

a. Predictors: (Constant), price

b. Dependent Variable: visitor satisfaction

Source: data processed using SPPS 17

Table 4 shows that the value of $\mathrm{R}$ Square is 0.823 . This means that the contribution of the effect of price on visitor satisfaction is equal to $82.3 \%$, while the remaining $17.7 \%$ is affected by other variables which are not included in this regression model.

The t-test

The t-test was used to determine whether there is a partial effect of price on visitor satisfaction (Y) or not.

Formulation of hypotheses

$\mathrm{H} 0$ : $\beta<0$ : there is no positive and significant effect of the price $(\mathrm{X})$ on visitor satisfaction $(\mathrm{Y})$

Ha: $\beta>0$ : there is a positive and significant effect of the price $(\mathrm{X})$ on visitor satisfaction $(\mathrm{Y})$

Below is the result of the calculation using SPSS 17:

Table 5

The t-test results

\section{Coefficients ${ }^{\text {a }}$}

\begin{tabular}{|cl|l|l|l|l|l|}
\hline \multirow{2}{*}{\multicolumn{2}{|l|}{}} & \multicolumn{2}{|l|}{$\begin{array}{l}\text { Unstandardized } \\
\text { Coefficients }\end{array}$} & $\begin{array}{l}\text { Standardized } \\
\text { Coefficients }\end{array}$ & \multicolumn{2}{l|}{} \\
\cline { 2 - 7 } & B & Std. Error & Beta & $\mathrm{t}$ & Sig. \\
\hline 1 & (Constant) & 3.445 & .847 & & 4.068 & .000 \\
& Price & .407 & .064 & .541 & 6.365 & .000 \\
\hline
\end{tabular}

a. Dependent Variable: Visitor Satisfaction

Source: data processed using SPPS 17

Table 5 shows the value of $t$ table is at a significance level of $5 \%$ (two-tailed) with the following equation:

$\mathrm{t}$ table $=\mathrm{n}-\mathrm{k}-1:$ alpha $/ 2$

$$
\begin{aligned}
& =100-1-1: 0.05 / 2 \\
& =98: 0.025 \\
& =1.984
\end{aligned}
$$

where:

n: total 
$\mathrm{k}$ : the number of independent variables

1: constant

Thus, the $t$ count $(6.365)$ is $>t$ table (1.984) and Sig. $(0.000)$ is $<0.05$. This means that the price has a significant effect on visitor satisfaction.

\section{CONCLUSIONS}

Based on the analysis of all the elicited data, it can be concluded that, partially, the price has a positive and significant effect on the visitors' satisfaction. It means that the price is a very sensitive factor in determining visitors' satisfaction. The visitors tend to be more satisfied with their visit once they perceive that the prices at the waterpark are lower than the currently set ones. This confirms previous studies on the factors, including price, which affect visitor satisfaction, specifically in the context of the waterpark. Therefore, the waterpark management should reformulate its pricing strategy to address this issue, e.g. by adjusting the prices to the visitors' financial capability, service quality, price competitiveness, or company profits.

This study is limited to some ways, including the used variables. Further studies need to add other factors such as destination image and service quality to gain a more comprehensive understanding of visitor satisfaction in the context of the waterpark industry.

\section{REFERENCES}

Creswell, J.W. (2013). Research Design: Qualitative, Quantitative, and Mixed Method Approaches. London: SAGE Publications

Dulyadhamapiromya, T. and Supeecha, S. (2018). How waterpark image, price fairness, and satisfaction create behavioral intentions: moderating effects of novelty-seeking. The 25th Annual ERES Conference

Falk, M. \& Scaglione, M. (2018). Effects of ski lift ticket discounts on local tourism demand. Tourism Review, 73(4):480-491

Jin, N.P., Lee, S. and Lee, H. (2015) The Effect of Experience Quality on Perceived Value, Satisfaction, Image and Behavioral Intention of Water Park Patrons: New versus Repeat Visitors. International Journal of Tourism Research, 17, $82-95$

Jin, N., Line, N. D., and Merkebu, J. (2016). The effects of image and price fairness: A consideration of delight and loyalty in the waterpark industry. International Journal of Contemporary Hospitality Management, 28(9), 1895-1914

Kotler, P., Bowen, J.T., Makens, J.C., and Baloglu S. (2016). Marketing for Hospitality and Tourism. Essex: Pearson

Lee, S. (2016). The Impact of Food Quality on Experiential Value, Price Fairness, Water Park Image, Satisfaction, and Behavioral Intention in the Context of Water Park. Culinary Science \& Hospitality Research, 22 (1), 87-95

Liestiande, H. (2016). Visitor Preference for Water Park in Bali. Proceedings of the Asia Tourism Forum 2016 
Malasevska, I and Haugom, E (2017). Optimal prices for alpine ski passes. Tourism Management, 64, 291-302

Isnaeni, F. (2018). Analysis of factors influencing visitor satisfaction at Owabong Waterpark. Management Analysis Journal, 7 (3), 9-18

Wu, W., Zhang, L., and Qiu, F. (2016). Determinants of tourism ticket pricing for ancient villages and towns: Case studies from Jiangsu, Zhejiang, Shanghai and Anhui provinces. Tourism Management, 30, 1-6 